\title{
LIGNOCELLULOSIC COMPOSITES FROM BRAZILIAN GIANT BAMBOO (GUADUA MAGNA). PART 2: PROPERTIES OF CEMENT AND GYPSUM BONDED PARTICLEBOARDS
}

\author{
Priscila C. de Araújo ${ }^{1}$; Larissa M. Arruda ${ }^{2}$; Cláudio H. S. Del Menezzi ${ }^{3}$; \\ Divino E. Teixeira ${ }^{4}$ Mário R. de Souza ${ }^{4}$
}

\begin{abstract}
In the first part of this study, the feasibility of manufacturing resin-bonded particleboard from the recently identified Brazilian giant bamboo (Guadua magna) was evaluated. In this second part, the main goal was to study the material properties of the cement and gypsum-composites made from that bamboo species. The effect of $\mathrm{CaCl}_{2}$ addition in the physical and mechanical properties was also evaluated. Initially, the hydration test was performed to determine the inhibition index of the bamboo particles in the cement and gypsum setting. Three concentrations of $\mathrm{CaCl}_{2}$ were used to produce bamboo cementbonded particleboards (BCBP): $0 \%, 2 \%$ and $4 \% . \mathrm{CaCl}_{2}$ was not added into bamboo gypsum-bonded particle boards (BGBP). Mechanical and physical properties were evaluated and nondestructive testing was performed as well. The inhibition index of Guadua magna in the cement or gypsum setting was classified as "low inhibition". The addition of $\mathrm{CaCl}_{2}$ at bamboo-cement boards increased the internal bonding and reduced the water absorption. Other properties were not significantly affected. The bamboocement boards presented higher bending strength and lower moisture content than bamboo-gypsum boards.
\end{abstract}

Keywords: Bamboo; cement; gypsum; inhibition; mineral-bonded composites.

\section{INTRODUCTION}

Inorganic bonded wood composites are usually made with a mixture of wood particles, mineral binder, additives and water. The most common mineral component is the cement and the setting process results in heat release due the hydration of cement in the presence of water (Iwakiri and Prata 2008). These panels can be used in many kinds of constructions (Falk 1994). Furthermore, the basic concept of production of these panels can be applied for producing shingles, blocks and bricks.

These composites have some advantages in comparison with resin-bonded composites: fire and biological resistance, high durability, good dimensional stability and low production cost (Del Menezzi et al. 2007, Falk 1994, Moslemi 1988). Besides, mineral composites generally use solid wood waste or other lignocellulosic material, including agricultural wastes. For this reason, these panels occupy a special place in the new eco-friendly economy as they provide for energy saving, conservation of natural resources and reduction in environmental pollution (Sudin and Swamy 2006).

\footnotetext{
${ }^{1}$ Forest Engineer, Department of Forest Engineering, Faculty of Technology, University of Brasília, Brasília - DF, PO Box 04357, 70904-970, Brazil.

${ }^{2}$ Forest Engineer, MSc Student in Forest Science. Department of Forest Engineering, Faculty of Technology, University of Brasília, Brasília - DF, PO Box 04357, 70904-970, Brazil.

${ }^{3}$ Adjunct Professor, Dr. Department of Forest Engineering, Faculty of Technology, University of Brasília, Brasília - DF, PO Box 04357, 70904-970, Brazil.

${ }^{4}$ Researcher, PhD. Forest Products Laboratory, Brazilian Forest Service, Brasília - DF, 70818-900, Brazil.

Corresponding author: cmenezzi@unb.br

Received: 16.05.2011 Accepted: 30.07.2011
} 
The increase in demand for raw material to manufacture wood composites, cellulose and paper have motivated many researches about the potential substitutes or complements for wood from planted and native forests (Papadopoulos et al. 2006). Therefore, there are many studies with bamboos species due to their good physical characteristics, low production cost. Additionally, it is probably the fastestgrowing and highest-yielding natural resource and construction material available to mankind (Beraldo and Rivero 2003, Sudin and Swamy 2006). In addition, bamboos are widely distributed in the world especially in tropical and subtropical zones of Asia and some countries of Latin America (Beraldo and Rivero 2003).

In our previous study (Arruda et al. 2011) technical feasibility of manufacturing resin-bonded particleboard from the newest discovered Brazilian bamboo species Guadua magna (Londoño \& Filg.) was evaluated. G. magna features characteristics such as 12.6-23.4 m of height and $6-12 \mathrm{~cm}$ of diameter and potential for applications in civil engineering, housing, furniture, general farm uses, etc. In rural localities of occurrence, it is traditionally used to build rustic homes, and other farm constructions, such as barns, fences, etc. (Filgueiras and Londoño 2006).

Some problems are reported in the literature regarding the utilization of bamboo into a matrix of mineral composites. Major problems are the inhibitory effect caused by bamboo on the cure of cement. Bamboo has in its composition sugars, starch and phenolic compounds all of which have a profoundly adverse effect on the setting and strength development of the Portland cement matrices (Sudin and Swamy 2006).

To solve this problem it is a common technique adding inorganic chemical additives in order to accelerate the cure of cement or use some pretreatments on the particles to remove inhibitory substances (Latorraca 2000). The accelerators mineralize the particles and neutralize the inherent substances of wood or bamboo that contains the inhibitory effect of the cure of the cement (Dix 1989). The principal accelerator used for decades is the $\mathrm{CaCl}_{2}$ (calcium chloride) because is an efficient accelerator of calcium silicate hydration and has low production cost (Latorraca 2000).

This research aimed at determining the technical feasibility of using particles of Guaduamagna (Londoño \& Filg.) to produce mineral composites bonded with cement and gypsum and study the effect of $\mathrm{CaCl}_{2}$ addition in physical and mechanical properties of these composites.

\section{MATERIALS AND METHOD}

\section{Cement or gypsum hydration test}

The reaction of cement or gypsum with water releases heat in an exothermic reaction and monitoring this heating loss can be used as a parameter to evaluate the inhibition index of cement and gypsum with bamboo (Latorraca 2000). In determining the inhibition index, an experiment was proposed according to Hofstrand et al. (1983), recently applied by Okino et al. (2005) and cited by Papadopoulos (2007). The bamboo particles were ground milled and screened in 60 mesh sieves and then mixed with cement or gypsum in a thermocouple in the following proportion: $15 \mathrm{~g}$ of bamboo powder (60 mesh), $200 \mathrm{~g}$ of cement or gypsum and $90.5 \mathrm{ml}$ of water. Two replicates were prepared for each mixture of bamboo particles and mineral agglutinant and one for the neat cement to determine the inhibition index of the cement or gypsum.

The temperature was recorded by inserting a type $\mathrm{J}$ thermocouple, connected to a data logger, into the neat cement or the mixture. The data were recorded at intervals of one minute during 24 hours. The inhibition index (I) was calculated according to equation 1 . The effect of hydration of the cement was classified according to table 1 . 


$$
I=\left[\frac{(T c-T m)}{T c} x \frac{(H m-H c)}{H c} x \frac{(S c-S m)}{S c}\right] x 100
$$

Where:

$\begin{array}{ll}\mathrm{Tc}= & \text { Maximum temperature of neat cement or gypsum, }\left({ }^{\circ} \mathrm{C}\right) \\ \mathrm{Tm}= & \text { Maximum temperature of the cement or gypsum-water-bamboo mixture, }\left({ }^{\circ} \mathrm{C}\right) \\ \mathrm{Hc}= & \text { Time to reach the maximum temperature of neat cement or gypsum, }(\mathrm{h}) \\ \mathrm{Hm}= & \text { Time to reach the max. temperature of cement or gypsum-water-bamboo mixture, }(\mathrm{h}) \\ \mathrm{Sc}= & \text { Hydration ratio of neat cement or gypsum, }\left({ }^{\circ} \mathrm{C} / \mathrm{h}\right) \\ \mathrm{Sm}= & \text { Hydration ratio of cement or gypsum-water-bamboo mixture, }\left({ }^{\circ} \mathrm{C} / \mathrm{h}\right)\end{array}$

Table 1. Classification of the lignocellulosic material according to the inhibition index.

\begin{tabular}{|c|c|}
\hline Inhibition Index $(\%)$ & Classification \\
\hline $\mathbf{I}<\mathbf{1 0}$ & Low inhibition \\
\hline $\mathbf{1 0}<\mathbf{I}<\mathbf{5 0}$ & Medium inhibition \\
\hline $\mathbf{5 0}<$ I $<\mathbf{1 0 0}$ & High inhibition \\
\hline $\mathbf{I}>\mathbf{1 0 0}$ & Very high inhibition \\
\hline
\end{tabular}

Source: Okino et al. (2004)

\section{Particles preparation and board manufacture}

The culms of bamboo were obtained in the state of Goiás, Brazilian Central-Western region. Initially, they were pretreated in cold water (room temperature) for one week to remove inhibitory substances (starch and sugar), and then processed into particles according to Arruda et al. (2011). Three concentrations of $\mathrm{CaCl}_{2}$ were evaluated to produce bamboo-cement boards: $0 \%, 2 \%$ and $4 \%$ (based on the dry weight of the cement in the mixture). $\mathrm{CaCl}_{2}$ was not added to the bamboo-gypsum boards, given that the hydration test indicated that the hydration of gypsum was not affected by the addition of bamboo. Three replications were manufactured for each treatment, resultingin 12 boards, with dimensions of $300 \mathrm{~mm}$ x $300 \mathrm{~mm}$ x $12.5 \mathrm{~mm}(\mathrm{w} \times 1 \times \mathrm{t}$ ). The bamboo: cement or gypsum ratio used was 1:2.75 and the water: cement or gypsum ratio was $1: 2.5$. The target density was $1.25 \mathrm{~g} / \mathrm{cm}^{3}$. The particles were wetted with a mixture of water and additive, and then the inorganic materials (cement or gypsum) were added. The mat was pressed at $3.0 \mathrm{~N} / \mathrm{mm}^{2}$ using a hydraulic press for 24 hours at room temperature. Subsequently, boards were conditioned at $(22 \pm 2)^{\circ} \mathrm{C}$ and $(60 \pm 2) \%$ relative humidity for 28 days to allow the complete cement and gypsum setting.

\section{Board Properties and Statistical Analysis}

The boards were trimmed and five samples measuring $50 \mathrm{~mm}$ x $200 \mathrm{~mm}$ (w x 1) were cut for static bending testing (modulus of elasticity, $\mathrm{E}_{\mathrm{M}}$ and modulus of rupture, $\mathrm{f}_{\mathrm{m}}$ ). After testing, the samples were cut into specimens of $50 \mathrm{~mm} \times 50 \mathrm{~mm}$ to evaluate internal bonding (IB), thickness swelling (TS, $2 \mathrm{~h}$ and 24h), water absorption (WA, $2 \mathrm{~h}$ and $24 \mathrm{~h}$ ), moisture content (MC) and density (D). The samples were tested according to NBR 14810-3 (ABNT 2002). 
Nondestructive evaluation of the samples was assessed by using Metriguard 239A Stress Wave Timer (SWT) equipment. This technique takes a wave produced by an impact in one side of the material, which travels along the length of the sample to reach an accelerometer at the other end. The time to reach this distance is displayed in the SWT device and used to calculate the stress wave velocity $\left(\mathrm{v}_{\mathrm{o}}\right)$. This unit $\left(\mathrm{v}_{0}\right)$ in addition to the materials density and acceleration due to gravity were used to determinate the dynamic modulus of elasticity ( $\left.\mathrm{E}_{\mathrm{d}}\right)$ according to Souza et al. (2011).

The results obtained were subjected to an analysis of variance (ANOVA) at 5\% significance level to identify significant differences. Fisher LSD test (Least Significant Difference) evaluated the means differences among treatments by pair wise comparisons, based on estimated marginal means and Tukey test at 5\% significance level. One model was tested to evaluate NDT variable to estimate mechanical properties $\left(\mathrm{E}_{\mathrm{M}}\right.$ and $\left.\mathrm{f}_{\mathrm{m}}\right)$ from $\mathrm{E}_{\mathrm{d}}$ and $\mathrm{v}_{0}$.

\section{RESULTS AND DISCUSSION}

\section{Effect of bamboo on hydration of cement and gypsum}

The inhibition index of bamboo Guadua magna with cement was $10.1 \%$ and may be considered low. This low inhibition of bamboo Guadua magna can be explained by the removal of inhibitory substances in the pretreatment with water. This value is consistent with the ones obtained by Ma (2005), for the bamboo Phyllostachys heterocycla, which presented inhibitory indices of $6 \%$ and $9 \%$ after treatments of extraction with hot water and cold water, respectively. Jorge et al. (2004) mention that just cold water treatment (at room temperature) was enough to several hardwood species to improve compatibility. Papadopoulos (2007) reported for eight Greek wood species, inhibition indexes from 7.44\% for poplar to $52-57 \%$ for beech and cypress.

In the present study, the addition of bamboo resulted in reduction in hydration ratio, in maximum hydration temperature (MHT) and increased the maximum hydration time to reach MHT. In cement mixed with bamboo the MHT reduced from $51^{\circ} \mathrm{C}$ to $34.9^{\circ} \mathrm{C}$ and the time to reach MHT increased $38 \%$ (Figure 1) and the hydration ratio reduced abruptly as much as $84.4 \%$, from $5.21^{\circ} \mathrm{C} / \mathrm{h}$ to $0.81^{\circ} \mathrm{C} / \mathrm{h}$.

The inhibition index of bamboo with gypsum was very low, $1.2 \%$, indicating that the hydration of gypsum was not affected by the addition of bamboo. The MHT increased slightly with addition of bamboo from $43.6^{\circ} \mathrm{C}$ to $45.7^{\circ} \mathrm{C}$, and the time to reach MHT increased, from 1.17 hours to 1.63 hours (Figure 2). Inversely, hydration ratio of gypsum increased from $19.6^{\circ} \mathrm{C} / \mathrm{h}$ to $31.7^{\circ} \mathrm{C} / \mathrm{h}$. The effect of bamboo on hydration curve of gypsum was not similar to the effect on cement hydration.

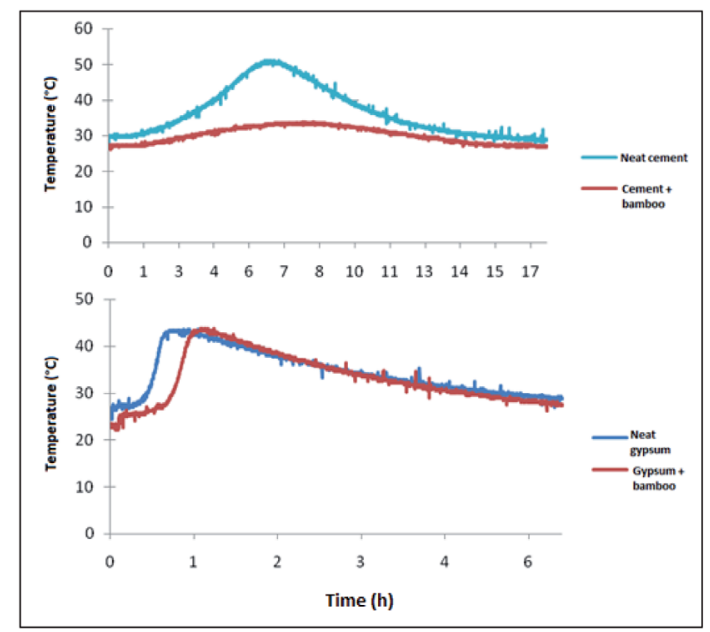

Figure 1. Hydration curve over the time of cement (a) and gypsum (b) mixtures. 


\section{Density of the boards}

Table 2 shows the results for density in each treatment. The bamboo-cement board with $4 \%$ of $\mathrm{CaCl}_{2}$ reached the highest density, $1.24 \mathrm{~g} / \mathrm{cm}^{3}$, and bamboo-gypsum without $\mathrm{CaCl}_{2}$ the lowest, $1.17 \mathrm{~g} / \mathrm{cm}^{3}$. According to table 2, density was not significantly different between bamboo-gypsum and bamboocement boards without additive $\left(1.17 \mathrm{~g} / \mathrm{cm}^{3}\right.$ and $1.18 \mathrm{~g} / \mathrm{cm}^{3}$, respectively), taking in account only the type of binder.

Table 2. Density means for bamboo-cement and bamboo-gypsum composites.

\begin{tabular}{|c|c|c|}
\hline Treatment & Density $\left(\mathrm{g} / \mathrm{cm}^{3}\right)$ & $\mathrm{CV}(\%)^{1}$ \\
\hline Bamboo-gypsum $0 \%$ & $1.17^{\mathrm{A}}$ & 3.74 \\
\hline Bamboo-cement $0 \%$ & $1.18^{\mathrm{A}}$ & 4.15 \\
\hline Bamboo-cement 2\% & $1.22^{\mathrm{B}}$ & 1.34 \\
\hline Bamboo-cement 4\% & $1.24^{\mathrm{C}}$ & 1.98 \\
\hline Structural board type $\mathrm{HZ}^{2}$ & 1.20 & - \\
\hline
\end{tabular}

The results are closed to the value proposed by Bison (1978) for a structural board type HZ. Boards type $\mathrm{HZ}$ are resistant to fungi, termites, fire and weathering, and have also good mechanicals properties. The methodology adopted by Bison (1978) is pioneer in producing mineral composites and for this reason is used in comparisons in literature (Okino et al. 2004). In boards with cement, the addition of $\mathrm{CaCl}_{2}$ increased the density.

\section{Effect of addition of $\mathrm{CaC}_{12}$ in bamboo-cement boards}

To evaluate exclusively the effect of addition of $\mathrm{CaCl}_{2}(0 \%, 2 \%$ and $4 \%)$ in bamboo-cement boards, given the significant difference among boards means, the values of mechanical and physical properties were estimated by the ANCOVA taking density as covariate to estimate the properties (Table 4).

The results in table 3 show that the addition of $\mathrm{CaCl}_{2}$ increases the moisture content (MC). The MC increased from $7.92 \%$ in bamboo-cement with $0 \% \mathrm{CaCl}_{2}$ to $10.5 \%$ in bamboo-cement with $4 \%$ of $\mathrm{CaCl}_{2}$. This may have occurred due to hygroscopic character of $\mathrm{CaCl}_{2}$, it is also a deliquescent substance has a strong affinity for moisture and absorb relatively large amounts of water from the atmosphere if exposed to it, forming a liquid solution. Only the boards without $\mathrm{CaCl}_{2}$ are within the limit of humidity specified by Bison (1978).

Table 3. Physical properties of bamboo-cement boards.

\begin{tabular}{|l|c|c|c|c|c|}
\hline \multirow{2}{*}{ Treatment } & \multirow{2}{*}{ MC (\%) } & \multicolumn{2}{c|}{ TS (\%) } & \multicolumn{2}{c|}{ WA (\%) } \\
\cline { 3 - 6 } & & 2h & 24h & 2h & 24h \\
\hline Bamboo-cement $\% \mathrm{CaCl}_{2}$ & $7.92^{\mathrm{A}}$ & $0.92^{\mathrm{A}}$ & $0.94^{\mathrm{A}}$ & $19.32^{\mathrm{A}}$ & $20.70^{\mathrm{A}}$ \\
\hline Bamboo-cement $2 \% \mathrm{CaCl}_{2}$ & $9.88^{\mathrm{B}}$ & $0.78^{\mathrm{A}}$ & $0.87^{\mathrm{A}}$ & $16.93^{\mathrm{AB}}$ & $19.61^{\mathrm{B}}$ \\
\hline Bamboo-cement $4 \% \mathrm{CaCl}_{2}$ & $10.50^{\mathrm{C}}$ & $1.20^{\mathrm{B}}$ & $0.92^{\mathrm{A}}$ & $15.50^{\mathrm{B}}$ & $19.28^{\mathrm{B}}$ \\
\hline Structural board type $\mathrm{HZ}^{1}$ & 9.0 & $0.8-1.3$ & $1.2-1.8$ & - & - \\
\hline
\end{tabular}

$\mathrm{MC}=$ moisture content; TS=thickness swelling; WA=water absorption. ${ }^{1}$ Cement-wood composites according to Bison (1978). Different letters in the same column indicate significant differences by the Tukey test at 5\% significance level. 
In TS $2 \mathrm{~h}$, boards with addition of $4 \%$ of $\mathrm{CaCl}_{2}$ obtained values $30.4 \%$ higher than boards without the chemical additive. After 24 hours, the addition did not affect the TS. However, the addition of $\mathrm{CaCl}_{2}$ reduced the WA, indicating that the effect of the hygroscopicity of $\mathrm{CaCl}_{2}$ is more pronounced on TS. Sudin and Swamy (2006) also experimented using bamboo particles mixed with and without $\mathrm{CaCl}_{2}$ and obtained values of TS slightly higher than those in this study. They also reported values of WA in the range of $24.6 \%$ to $26.1 \%$, above the ones observed in the present study.

In cement-wood composites made with Eucalyptus urophylla and $4 \%$ of $\mathrm{CaCl}_{2}$ as additive, Silva et al. (2006) obtained similar values of those from bamboo composites. After 2 hours immersion, TS was $0.68 \%$ and $1.49 \%$ after 24 hours. These authors observed lower values for WA $(5.41 \%$ in 2 hours and $8.51 \%$ after 24 hours), indicating that cement-wood composites are more resistant to water absorption than bamboo-cement ones.

Table 4 shows the results to mechanical properties of bamboo-cement composites. The IB values are below the minimum required by Bison (1978), $0.40 \mathrm{~N} / \mathrm{mm}^{2}$. The IB ranged from 0.21 to 0.31 $\mathrm{N} / \mathrm{mm}^{2}$, increasing $31 \%$ with addition of $2 \%$ of $\mathrm{CaCl}_{2}$ and $45.2 \%$ with addition of $4 \%$ of $\mathrm{CaCl}_{2}$. The IB values for bamboo-cement composites are lower than values obtained for wood-cement composites, possibly due to the higher density of wood species over bamboo, however this study provided boards with higher strength as compared to the values of 0.12 to $0.19 \mathrm{~N} / \mathrm{mm}^{2}$ reported by Sudin and Swamy (2006). Regarding wood-cement bonded composites, Silva et al. (2006) reported an IB value of 0.68 $\mathrm{N} / \mathrm{mm}^{2}$ and average density of $1.35 \mathrm{~g} / \mathrm{cm}^{3}$ for composites of Eucalyptus urophylla with addition of $4 \%$ $\mathrm{CaCl}_{2}$. Iwakiri and Prata (2008) producing similar composites, with Pinus taeda reported an IB value of $0.46 \mathrm{~N} / \mathrm{mm}^{2}$ with an average density of $1.19 \mathrm{~g} / \mathrm{cm}^{3}$. It is clear that the addition of $\mathrm{CaCl}_{2}$ did not affect flexural properties.

Table 4. Estimated mechanical properties of bamboo-cement boards.

\begin{tabular}{|c|c|c|c|c|c|}
\hline Treatment & $\mathbf{E}_{\mathbf{M}}$ & $\mathbf{f}_{\mathbf{m}}$ & IB & $\mathbf{E}_{\mathbf{d}}$ & $\mathbf{v}_{\mathbf{0}}$ \\
\hline & \multicolumn{4}{|c|}{ - } & $----\mathbf{m} / \mathbf{s}----$ \\
\hline Bamboo-cement $0 \% \mathrm{CaCl}_{2}$ & $3,083^{\mathrm{A}}$ & $7.66^{\mathrm{A}}$ & $0.21^{\mathrm{A}}$ & $4,518^{\mathrm{A}}$ & $1,908^{\mathrm{A}}$ \\
\hline Bamboo-cement $2 \% \mathrm{CaCl}_{2}$ & $3,114^{\mathrm{A}}$ & $7.91^{\mathrm{A}}$ & $0.28^{\mathrm{B}}$ & $4,484^{\mathrm{A}}$ & $1,902^{\mathrm{A}}$ \\
\hline Bamboo-cement $4 \% \mathrm{CaCl}_{2}$ & $3,022^{\mathrm{A}}$ & $7.36^{\mathrm{A}}$ & $0.31^{\mathrm{C}}$ & $4,339^{\mathrm{A}}$ & $1,869^{\mathrm{A}}$ \\
\hline Structural board type $\mathrm{HZ}^{1}$ & 3,000 & 9.0 & 0.40 & - & - \\
\hline
\end{tabular}

$\mathrm{E}_{\mathrm{M}}=$ modulus of elasticity; $\mathrm{f}_{\mathrm{m}}=$ modulus of rupture; $\mathrm{IB}=$ internal bond; $\mathrm{E}_{\mathrm{d}}=$ dynamic modulus of elasticity; ${ }^{1}$ Cement-wood composites according to Bison (1978). Different letters in the same column indicate significant differences by the Tukey's test at $5 \%$ significance level. $\mathrm{v}_{0}=$ stress wave velocity.

The values of the flexural properties are within a range usually encountered in the literature. Compared with Sudin and Swamy (2006), that reported maximum value of $5.48 \mathrm{~N} / \mathrm{mm}^{2}$ for modulus of rupture on boards of bamboo with and without $\mathrm{CaCl}_{2}$, the strength of the boards of this study were superior, in the range of 7.36 to $7.91 \mathrm{~N} / \mathrm{mm}^{2}$. Silva et al. (2006) and Iwakiri and Prata (2008) reported for woodcement composites values to $\mathrm{E}_{\mathrm{M}}\left(3,224 \mathrm{~N} / \mathrm{mm}^{2}\right.$ and $\left.4,290 \mathrm{~N} / \mathrm{mm}^{2}\right)$ and $\mathrm{fm}\left(20.75 \mathrm{~N} / \mathrm{mm}^{2}\right.$ and $9.41 \mathrm{~N} /$ $\mathrm{mm}^{2}$ ). The modulus of rupture of the treatments did not reach the minimum value required specified by Bison (1978), $9.0 \mathrm{~N} / \mathrm{mm}^{2}$. On the other hand, all treatments reached the minimum required $(3,000 \mathrm{~N} /$ $\mathrm{mm}^{2}$ ) to modulus of elasticity.

The $\mathrm{E}_{\mathrm{d}}$ values determined using NDT methods are usually higher than $\mathrm{E}_{\mathrm{M}}$. Targa et al. (2005) suggest that it occurs due to viscoelastic behavior of wood, and it is a negative point of the nondestructive evaluation. However, NDT assessment provides a quickly evaluation of quality control of the panels (Ross and Pellerin 1988) and can be used to estimate static bending properties. 


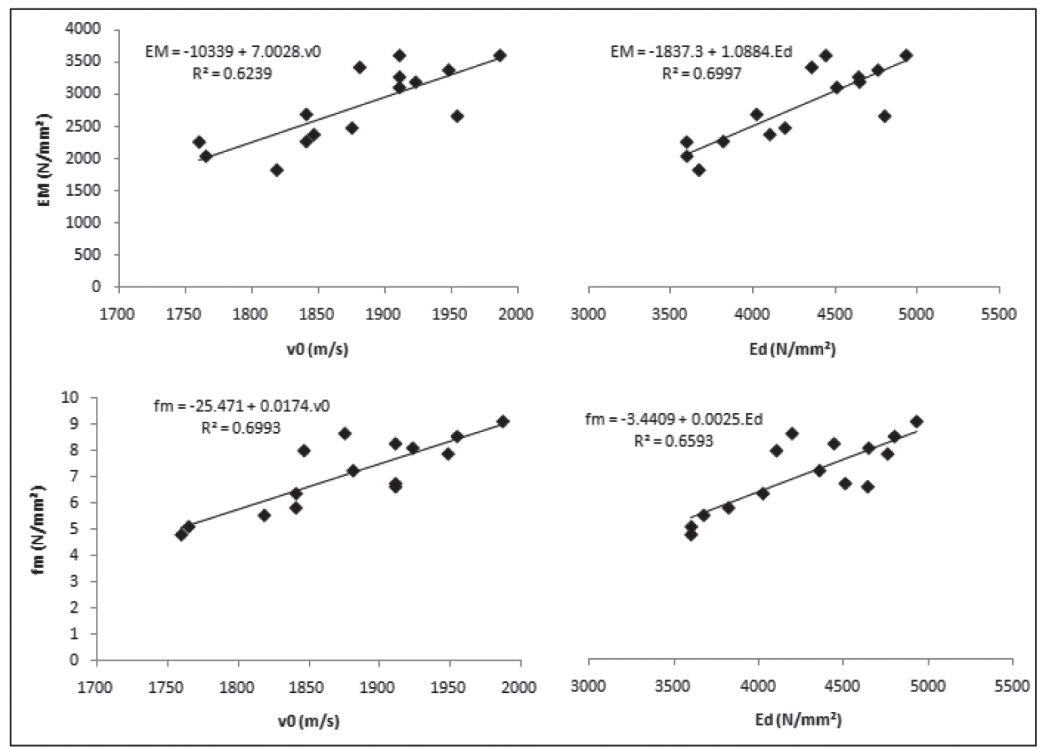

Figure 2. Simple linear regression to estimate flexural properties of bamboo-cement board $\left(0 \% \mathrm{CaCl}_{2}\right)$ using stress wave method.

Using linear regression models to estimate $\mathrm{E}_{\mathrm{M}}$ and $\mathrm{f}_{\mathrm{m}}$ from $\mathrm{E}_{\mathrm{d}}$ and $\mathrm{v}_{0}$, only the treatment without additive had acceptable coefficient of determination $\left(\mathrm{R}^{2}\right)$ i.e., $\mathrm{R}^{2}>0.60$. In treatments with addition of $\mathrm{CaCl}_{2}, \mathrm{E}_{\mathrm{d}}$ and $\mathrm{v}_{0}$ did not present a significant relationship with $\mathrm{E}_{\mathrm{M}}$ or $\mathrm{f}_{\mathrm{m}}$. Figure 2 shows the regressions of bamboo-cement $0 \%$ of $\mathrm{CaCl}_{2}$. With relation to stress wave velocity, the values reduced as the addition of $\mathrm{CaCl}_{2}$ increased

\section{Effect of mineral binder}

In physical properties, gypsum provides an increasing in MC, TS $24 \mathrm{~h}$ and WA $2 \mathrm{~h}$ and $24 \mathrm{~h}$ (Table 5). In TS $2 \mathrm{~h}$, the values are not significantly different. The MC of bamboo-gypsum boards was almost two fold the MC of bamboo-cement boards. In addition, gypsum increased in $15 \%$ the TS $24 \mathrm{~h}, 9.67 \%$ the WA $2 \mathrm{~h}$ and $10.81 \%$ the WA $24 \mathrm{~h}$. This probably occurred because gypsum is more hygroscopic than cement. Haselein et al. (2002) observed that the addition of lignocellulosic materials to gypsum reduces WA and increase the TS.

Table 5. Observed physical properties of bamboo-gypsum and bamboo-cement boards.

\begin{tabular}{|c|c|c|c|c|c|}
\hline \multirow[t]{2}{*}{ Treatment } & \multirow[t]{2}{*}{$\operatorname{MC}(\%)$} & \multicolumn{2}{|c|}{ TS (\%) } & \multicolumn{2}{|c|}{ WA $(\%)$} \\
\hline & & $2 h$ & $24 \mathrm{~h}$ & $2 h$ & $24 \mathrm{~h}$ \\
\hline $\begin{array}{l}\text { Bamboo-gypsum 0\% } \\
\mathrm{CaCl}_{2}\end{array}$ & $15.40^{\mathrm{A}}$ & $0.93^{\mathrm{A}}$ & $1.07^{\mathrm{A}}$ & $21.53^{\mathrm{A}}$ & $24.18^{\mathrm{A}}$ \\
\hline $\begin{array}{l}\text { Bamboo-cement 0\% } \\
\mathrm{CaCl}_{2}\end{array}$ & $7.83^{\mathrm{B}}$ & $0.97^{\mathrm{A}}$ & $0.93^{\mathrm{B}}$ & $19.63^{\mathrm{B}}$ & $21.82^{\mathrm{B}}$ \\
\hline
\end{tabular}

$\mathrm{TS}=$ thickness swelling; WA = water absorption. Different letters in the same column indicate significant differences by the Tukey's test at $5 \%$ significance level. 
In static bending, only $\mathrm{f}_{\mathrm{m}}$ values were significantly different (Table 6). The bamboo-cement boards were more resistant than bamboo-gypsum, whose values were $7.13 \mathrm{~N} / \mathrm{mm}^{2}$ and $5.0 \mathrm{~N} / \mathrm{mm}^{2}$, respectively. The IB was very similar in cement and gypsum boards $\left(0.21 \mathrm{~N} / \mathrm{mm}^{2} \mathrm{x} 0.20 \mathrm{~N} / \mathrm{mm}^{2}\right)$. Haselein et al. (2002) studied gypsum-wood composite with Pinus elliottii and obtained an $\mathrm{f}_{\mathrm{m}}$ value slightly lower than bamboo-gypsum composite. When scraps of paper reinforced these gypsum-wood composites, the $\mathrm{f}_{\mathrm{m}}$ increased in $102 \%$ (from $4.13 \mathrm{~N} / \mathrm{mm}^{2}$ to $8.35 \mathrm{~N} / \mathrm{mm}^{2}$ ).

Table 6. Observed mechanical properties of bamboo-gypsum and bamboo-cement boards

\begin{tabular}{|c|c|c|c|c|c|}
\hline Treatment & $\mathbf{E}_{\mathbf{M}}$ & $\mathbf{f}_{\mathbf{m}}$ & IB & $\mathbf{E}_{\mathbf{d}}$ & $\mathbf{v}_{\mathbf{0}}$ \\
\hline & \multicolumn{4}{|c|}{ 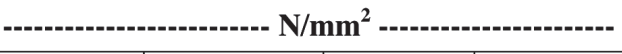 } & ---m/s--- \\
\hline Bamboo-gypsum $0 \% \mathrm{CaCl}_{2}$ & $2,655^{\mathrm{A}}$ & $5.00^{\mathrm{B}}$ & $0.20^{\mathrm{B}}$ & $4,435^{\mathrm{A}}$ & $1,924^{\mathrm{A}}$ \\
\hline Bamboo-cement $0 \% \mathrm{CaCl}_{2}$ & $2,812^{\mathrm{A}}$ & $7.13^{\mathrm{A}}$ & $0.21^{\mathrm{A}}$ & $4,272^{\mathrm{A}}$ & $1,878^{\mathrm{B}}$ \\
\hline
\end{tabular}

$\mathrm{E}_{\mathrm{M}}=$ Modulus of Elasticity; $\mathrm{f}_{\mathrm{m}}=$ Modulus of Rupture; IB = Internal Bond; $\mathrm{E}_{\mathrm{d}}=$ Dynamic Modulus of Elasticity. Different letters in the same column indicate significant differences by ANOVA at $5 \%$ significance level.

In table $6, \mathrm{E}_{\mathrm{d}}$ overestimated the EM in $67 \%$ to bamboo-gypsum boards and in $51.9 \%$ in bamboocement boards. The values are not significantly different, but $\mathrm{E}_{\mathrm{d}}$ in gypsum was higher than in cement boards. This is directly correlated to the highest value obtained by the $\mathrm{v}_{0}$ in gypsum boards. This independent variable had low correlation with $\mathrm{f}_{\mathrm{M}}$ and $\mathrm{E}_{\mathrm{M}}$. Otherwise, $\mathrm{E}_{\mathrm{d}}$ had good correlation with $\mathrm{E}_{\mathrm{M}}$ and $\mathrm{f}_{\mathrm{M}}$, especially in gypsum boards, $\mathrm{R}^{2}=0.75$ (Figure 3 ).

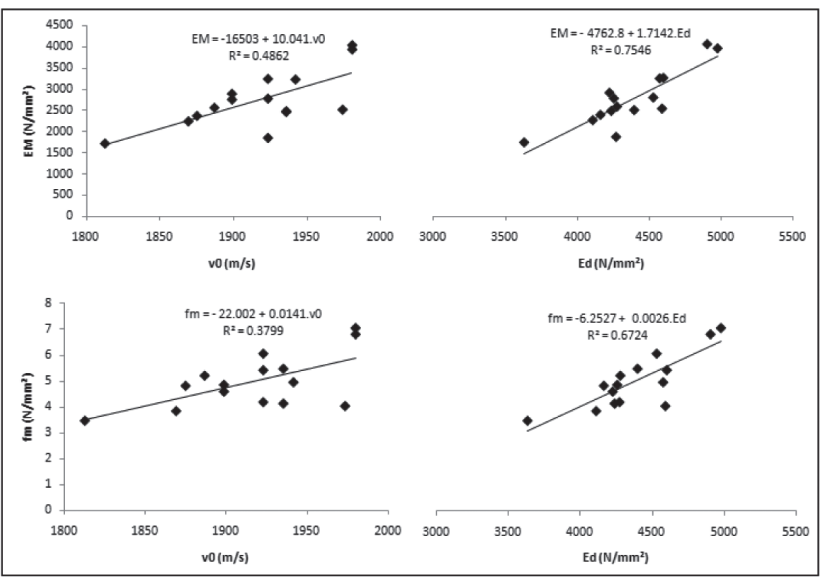

Figure 3. Linear regressions of bamboo-gypsum $0 \% \mathrm{of} \mathrm{CaCl}_{2}$

\section{CONCLUSIONS}

According to the hydration test, the inhibition index of Guadua magna in cement and in gypsum was classified as "low inhibition", although this value for gypsum is almost insignificant. The addition of $\mathrm{CaCl}_{2}$ to bamboo-cement boards increased the IB and reduced the WA. Other properties were not affected significantly. The bamboo-cement boards were more resistant in $\mathrm{fm}$ and had lower MC than bamboo-gypsum boards. In general, Guadua magna is suitable to produce cement and gypsum composites, although some aspects still need to be studied: the influence of particle size; others chemical additives and their proportions; and addition of other lignocellulosic materials, such as wood. 


\section{ACKNOWLEDGMENTS}

To National Council for Scientific and Technological Development (CNPq) for providing Scholarship Grant to the first author.

\section{REFERENCES}

Arruda, L. M.; Del Menezzi, C. H. S.; Teixeira, D. E.; Araújo, P. C. de. 2011. Lignocellulosic composites from Brazilian giant bamboo (Guadua magna) Part 1: Properties of resin bonded particleboards. Maderas. Ciencia y tecnología. 13(1): 49-58.

ABNT, Associação Brasileira de Normas Técnicas 2002. Chapas de Madeira Aglomerada. Designation: NBR 14.810, Rio de Janeiro, Brazil. 32pp.

Beraldo, A. L.; Rivero, L.A. 2003. Bambu laminado Colado (BLC). Floresta e Ambiente 10 (2): $36-46$.

BISON. 1978. Wood-Cement Board. Report. British Research Establishement (Bre). Uk. 1-65.

Del Menezzi, C.H.S.; Castro, V.G.; Souza, M.R. 2007. Production and properties of a medium density wood-cement boards produced with oriented strands and silica fume. Maderas. Ciencia y tecnología 9(2): 105-115.

Dix, R.J.H. 1989. The principles of cement-bonded particleboard manufacture. In: Proceedings 2th. International Conference on Fiber and Particleboards Bonded with Inorganic Binders. Moscow, ID, USA. 48-52

Falk, R. H. 1994. Building products from recycled wood waste. In: Proceedings, $12^{\text {th }}$ annual Excellence in housing conference and exposition. Dallas, USA, TX: Wausau, WI: Energy Efficient Building Association: E1-E6, 23-26 February 1994.

Filgueiras, T.S.; Londoño, X. 2006. A Giant new Guadua (Poaceae: Bambusoideae) from Central Brazil. In: Proceedings of Seminário Nacional Estruturação da Rede de Pesquisa e Desenvolvimento do Bambu, 1, Brasília, 13-15 September 2006. Brasília. Brasil. 27p.

Haselein, C.R; Calegari, L.; Alberti, L.F.; Minello, A.L.; Silva, P.A.; Pintos, R.G.F. 2002. Fabricação de chapas de partículas aglomeradas usando gesso como material cimentante. Ciência Florestal 12(1): 81-88.

Hofstrand, A.D.; Garcia, J.F.; Moslemi, A.A. 1983. Effect of various treatments and additives on wood-Portland cement-water systems. Wood and Fiber Science 15 (2): 163- 175.

Iwakiri, S.; Prata, J. G. 2008. Utilização da madeira de Eucalyptus grandis e Eucalyptus dunnii na produção de painéis de cimento-madeira. Cerne 14( 1): 68-74

Jorge, F. C.; Pereira, C.; Ferreira, J. M. F. 2004. Wood-cement composites: a review. Holzals Roh-und Werkstoff 62 (5):370-377.

Latorraca, J.V.F. 2000. Eucalyptus spp. na produção de painéis de cimento-madeira. PhD Thesis, Universidade Federal do Paraná, Curitiba, Paraná. 
Ma, L. 2005. Manufacture of Bamboo-Cement Particle board. In: Proceedings International Workshop on Prefabricated Housing from Bamboo Based Panels Institute of Wood Science and Technology, Zhejiang Forestry University, Linan, Zhejiang, China. 24-25 November 2005. 8pp.

Moslemi, A. A. 1988. Wood-cement panel products: coming of age. In: Proceedings 1st. International Conference on Fiber and Particleboards Bonded with Inorganic Binders. Moscow, ID, USA. 24-26 October 1998. 2-18.

Okino, E. Y. A.; Souza, M. R.; Santana, M. A. E.; Alves, M. V. da S.; Sousa, M. E. de; Teixeira, D. E. 2005. Physico-mechanical properties and decay resistance of Cupressus spp. cement-bonded particleboards. Cement \& Concrete Composites 27(3): 333-338.

Okino, E.Y.A.; Souza, M.R.; Santana, M.A.E.; Sousa, M.E.; Teixeira, D. E. 2004. Chapa aglomerada de cimento-madeira de Hevea brasiliensis Müll. Rev. Árvore 28 (3): 451-457.

Papadopoulos, A.N. 2007. An investigation of the suitability of some Greek wood species in woodcement composites manufacture. Holz als Roh-und Werkstoff 65(3): 245-246.

Papadopoulos, A.N.; Ntalos, G.A.; Kakaras, I. 2006. Mechanical and physical properties of cement-bonded OSB. Holzals Roh-und Werkstoff 64 (6): 517-518.

Ross, R.J.; Pellerin, R.F. 1988. NDE of wood-based composites with longitudinal stress waves. Forest Products Journal 38 (5): 39-45.

Silva, G.C.; Latorraca, J.V.F.; Carmo, J. F.; Ferreira, E.S.F. 2006. Efeito de aditivos minerais sobre as propriedades de chapas cimento-madeira. Rev. Árvore 30 (3): 451-456.

Souza, F.; Del Menezzi, C. H. S.; Bortoletto Jr., G. 2011. Material properties and nondestructive evaluation of laminated veneer lumber (LVL) made from Pinus oocarpa and P. kesiya. European Journal of Wood and Wood Products 69 (2): 183-192.

Sudin, R.; Swamy, N. 2006. Bamboo and wood fiber cement composites for sustainable infrastructure regeneration. Journal of Materials. Science 41(21): 6917-6924.

Targa, L. A.; Ballarin, M. A.; Biaggioni, M. A. M. 2005. Avaliação do módulo de elasticidade da madeira com uso de método não-destrutivo de vibração transversal. Engenharia Agrícola 25(2): 291-299. 